${ }^{\odot}$ Entomologica Fennica. 15 June 2003

\title{
Red Admirals Vanessa atalanta (Lepidoptera: Nymphalidae) select northern winds on southward migration
}

\author{
Kauri Mikkola
}

\begin{abstract}
Mikkola, K. 2003: Red Admirals Vanessa atalanta (Lepidoptera: Nymphalidae) select northern winds on southward migration. — Entomologica Fennica 14: $15-24$.
\end{abstract}

In the autumn periods of 1994-2001, the migrations of the Red Admiral Vanessa atalanta (L.) were recorded from the Porkkala Bird Tower, $35 \mathrm{~km}$ SW of Helsinki, Finland. By far the best year was 1998, when 1240 migrant $V$. atalanta were counted. Generalized to a $100-\mathrm{km}$ strip, this would mean a minimum of half a million butterflies. Radar observations indicated that a large proportion may have migrated above the visible range. The migrations took place on sunny days with cool northern winds (down to $+10-13^{\circ} \mathrm{C}$ ). On warmer days with southern winds, $V$. atalanta individuals were stationary in the terrain. Other species observed to migrate south in the same way, but in much lower numbers, included Vanessa cardui (L.), Pieris brassicae (L.) and Autographa gamma (L.). These records help to resolve the "evolutionary puzzle" of why migrant butterflies and moths travel to northern latitudes when their offspring have such limited possibilities of returning to the south. Until now, the only butterfly for which high-elevation return migrations in northern winds have been known has been the American Monarch Danaus plexippus (L.). The mechanics of the flights, the migratory behaviour and their evolutionary significance are discussed in light of the literature.

Kauri Mikkola, Zoological Museum, P.O. Box 17, FIN-00014 University of Helsinki,Finland; E-mail: kauri.mikkola@helsinki.fi

Received 2 July 2002, accepted 17 October 2002

\section{Introduction}

The selective value of seasonal migrations of Lepidoptera to northern latitudes has caused confusion among researchers for a century. It has often been argued that the populations reproducing in the north-temperate regions during the short summer are being lost. Williams (1958) stated that if this is the case, the migrations "must be in the nature of overflows from a permanent breeding ground".
The ill fate of the migrants appears to be inevitable. During the northward migration, these butterflies and moths utilize warm southern air currents (for Finland, situated roughly north of $60^{\circ} \mathrm{N}$, see Mikkola [1967, 1986]). In late summer, there are no warm currents directed from north to south, however. How, then, can these populations of more or less thermophilous species return to their distant hibernation areas? If they die, why is the migratory behaviour maintained in the populations, even as a kind of genetic load? 
To overcome the "evolutionary dilemma", Kettlewell (1952) developed a genetic model explaining how a considerable proportion of total populations can be lost, but the migratory behaviour is still retained. According to the model, butterflies homozygous for the allele $M$ would be compulsory migrants, those homozygous for the allele $m$ would be non-migrants and heterozygotes would migrate in advantageous environmental conditions only.

An early proponent of the ability of migrating insects to gain advantage from the great wind speeds at high altitudes was Felt $(1925,1928)$. He did not, however, consider the possibility that insects would orientate themselves in the direction of the wind or select the wind direction.

Williams (1930) admitted that "butterflies may take advantage of a following wind by rising higher", but "there is a direction in which they are urged to go". In general, he tried to show that highelevation mid-wind flights are an unimportant part of the migrations, except for the American Monarch Danaus plexippus (L.). He wondered whether an insect could be conscious of any uniform movement of the air, and he discussed the possibility that the gusts could cause a sensing of the direction. Johnson (1969) was also most careful on this point: "wind cannot be neglected completely [as in Baker's (1968) theory] when the displacements of whole populations are involved". Dennis (1993) states that "direction is largely independent of wind direction", except for "long-distance spring migrations" being "enhanced by warmer meridional air streams". Pollard (1982) presented the view that the regular movements of $D$. plexippus are "quite different from the erratic movements of" Vanessa cardui (L.).

Numerous observations exist from Europe of southerly migrations of Vanessa atalanta (L.), but they are usually low-altitude migrations, often against the wind (e.g. Williams 1958, Johnson 1969, Stefanescu 2001). Benvenuti et al. (1994) argue against "passive displacements caused by winds" of $V$. atalanta and suggest "regular bidirectional migration" based on compass orientation.

In Finland, as elsewhere in Northern Europe, it has been a long-lasting point of astonishment why so few observations of southward migrations exist when northward migrations are frequently observed both visually and through the time sched- ule of arrivals (Kaisila 1962). The arrivals are clearly correlated with certain, mainly southern to south-eastern, air currents (Mikkola 1967). Kaisila (1962) supposed that $V$. atalanta migrates southward in autumn because the butterflies regularly disappear late in the season. Tucker (1997) recently added that "following a veer of wind direction to a more northerly point, the butterflies are found to have gone". Both seem to have been correct.

Flights against the wind, or compass-oriented flights, can hardly constitute missing evidence for long-range return migrations. The physiological obstacle caused by the distances involved and by the powerful flight needed would supposedly be insurmountable. Benvenuti et al. (1994) report the mean speed of Vanessa atalanta as $14 \mathrm{~km} / \mathrm{h}$. This seems to be far less than what is needed for migrations of the order of a few thousand kilometres. Nevertheless, in October and early November Admirals from Northern and Central Europe arrive at Catalonia, Spain, in good numbers and initiate a period of intensive breeding (Stefanescu 2001).

The data on flights at low altitude probably only cover a small portion of the populations. Even if indicative of the tendency for southward flight of the butterflies, they hardly constitute an evolutionary explanation for the phenomenon discussed.

In recent years, the paradox has little by little been unravelled in Finland as a result of regular observations of medium-elevation "above-forest" flights. The credit mainly goes to a small group of ornithologists that has, over the course of several years, made observations on butterflies as well as on birds.

There is a tradition of some fifty years in Finland to follow up the visible migration of birds on the peninsulas and higher cliffs along the coasts. In addition to bird observatories, the existence of several bird towers facilitate observations and allow for more effective, better organized data gathering. The study of insect migration has now benefited from this ornithological tradition.

\section{Material and methods}

The present analysis of the late-season migrations of the Red Admiral Vanessa atalanta, and to a lesser extent of 
Fig. 1. The Porkkala Bird Tower in the background (arrow) projects out of the surrounding terrain. Photo: Karno Mikkola.

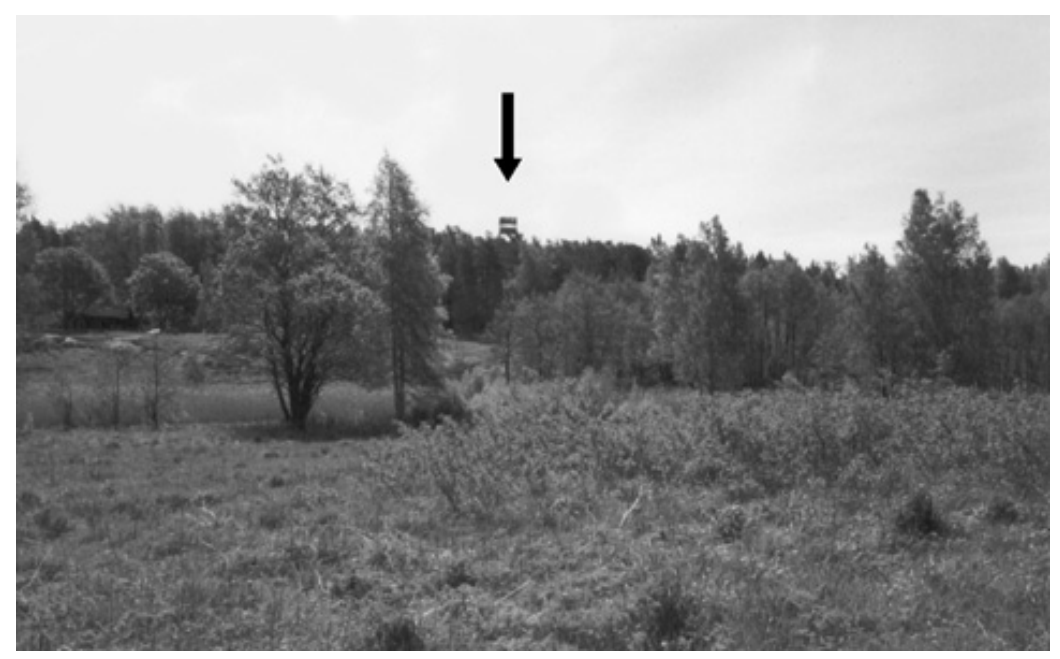

some other migrant Lepidoptera, is mainly based on observations from the Porkkala Bird Tower (59 $59^{\circ} \mathrm{N} 24^{\circ} 27^{\prime} \mathrm{E}$; Fig. 1), around $35 \mathrm{~km} \mathrm{SW}$ of Helsinki. The tower is situated on Porkkala Peninsula, only half a kilometre from the closest shore of the Gulf of Finland (Southeast of the tower) on a rocky outcrop $25 \mathrm{~m}$ above sea level. The tower itself is $11 \mathrm{~m}$ high, the highest tree tops on the same cliff remaining about $5 \mathrm{~m}$ below the observation level. Due to the relatively deep valleys with meadows around the tower (mainly on its western side; Fig. 1), the butterflies scanned horizontally from the tower actually fly some $15-30 \mathrm{~m}$ above ground or some $10-20 \mathrm{~m}$ above tree tops.

The main observers have been P. Komi, Karno Mikkola and S. Michelsson ( $\dagger$ ), and other observers include Ch. Catani and $\mathrm{O}$. Vesikko. The primary observation periods have been from late August to early October. Only a few days with reasonable weather have remained unobserved. The butterflies were generally found in conjunction with birds being scanned in the sky, usually in roughly horizontal direction above the forest. All butterflies with a clear orientation above tree tops were included; those which dropped down again were noted but are not treated here. Unidentified individuals have been noted as "large darks", and these have been included, according to the majority, as $V$. atalanta. Their numbers are mentioned as "indet." (undetermined).

Some important observations were made at Porkkala Bird Observatory on the island of Rönnskär, $6.5 \mathrm{~km}$ Southwest of the tower, by K. Saarvola and others, and at Hanko Bird Observatory, $88.5 \mathrm{~km}$ WSW of the tower, mainly by J. Haapala, P. Pynnönen and J. Ruoho. Other observations have been received for the most part from the annual gathering of data on lepidopteran migrants by the Lepidopterological Society of Finland: reports in the journal Baptria, cited below; observers mentioned in the text. From these reports, the yearly early season (until about 10 July) and late season totals are cited for the years 1994-2001.

Radar films from the former Department of Meteorology (presently, the Division of Atmospheric Sciences) of the University of Helsinki, particularly for 20 September 1998 (Matti Leskinen), and the aphid observations from the Pest Research Centre, Jokioinen (Irmeli Markkula) were consulted.

\section{Results}

\subsection{The observations}

The earliest observation of a high-flying south-migrating Vanessa atalanta is from 1981 [translated from Mikkola 1981]: “An interesting observation was made at U:Kirkkonummi $[10 \mathrm{~km} \mathrm{~N}$ of the Porkkala Tower] on 12.9.: One $V$. atalanta flying 20-30 $\mathrm{m}$ above the tree tops, mainly gliding, towards the SW, was followed for $500 \mathrm{~m}$, wind 2 beauf. N (J. Palmgren). Southern migration of this species has probably not been seen earlier in this country."

\section{4}

Total: 17/ca. 2000 (early season/late season observations). On 12 August, I observed a $V$. atalanta rising by circling like a raptor as high as was visible with a binocular and disappearing with the wind to the SW (Hanko Peninsula); another was seen on 23 August flying at high elevation in a tailwind to WSW (Porkkala Bird Tower). Some additional specimens were seen closer to the ground proceeding in southerly directions into a headwind (Mikkola 1996a). 
1995

$118 / 2691$. No south migrations of $V$. atalanta were reported (Mikkola 1996b).

1996

30/600. Hardly any signs of return migration were seen in V. atalanta (Mikkola 1997).

1997

11/283. Very poor year (Mikkola 1998).

1998

210/ca. 100 000. This was the occasion of the unravelling of southerly migrations of $V$. atalanta (Mikkola 1999). The total of migrating $V$.atalanta counted in September from the Porkkala Bird Tower was 1240 (418 of which were "large darks") (Table 1, Figs. 2-3). All of these migrated in southern directions with northerly winds, except for some 20 butterflies that flew NW when the wind had veered to the Southeast. Among $V$. atalanta, the following other migrants were noted on their way south: Vanessa cardui 6 exx., Pieris brassicae (L.) 28 exx. and Autographa gamma (L.) 9 exx.

The migration had begun a few days before the start of observations at the Tower. The Hanko Bird Station reported on 26 August 1998 that "numbers of large, dark butterflies were rising with a tailwind to SE" and the migration stopped when the wind turned to SE (J. Haapala, J. Ruoho). Both on 2 September and 3 September, around 300400 migrating $V$. atalanta were observed; on the latter date "also at a great height, more than 100 m”. The last tens were seen on 5 September. More than 100 exx. were again seen on 20 September, migrating with a NW wind, some of them very high up, found when migrating cranes were counted with a telescope. Near the town of Hanko on 19 September, ca. 30 butterflies were observed to glide at high elevations SSE with the wind, some of them at very high altitude (50-200 m; Jarmo Koistinen), and at another locality nearby, 10-15 $V$. atalanta were recorded as mainly gliding SSE with the wind (observer not recorded).

A migration flow was seen at Kirkkonummi, $13.5 \mathrm{~km} \mathrm{~N}$ of the Tower, on 22 September 1998: 296 exx. of $V$. atalanta slightly above the tree tops with the wind in a southern direction (K. Saarvola).

Table 1. The migrations of Vanessa atalanta observed from the Porkkala Bird Tower in September 1998. For locality and for the observers, see text. Indet. = "large darks". Cf. Fig. 3.

\begin{tabular}{|c|c|c|c|c|c|c|}
\hline Date & Time & Wind $\mathrm{m} / \mathrm{s}$ & Cloudiness & Total & Indet. & Dir. \\
\hline 1.IX. & 09:30-15:30 & NNE 6 & $4 / 8$ & 158 & 69 & SSW \\
\hline 2.IX. & $09: 10-14: 00$ & NE 3-4 & $1 / 8$ & 305 & 148 & SW \\
\hline 2.IX. & $14: 00-16: 30$ & SE 3 & $1 / 8$ & 20 & - & NW \\
\hline 3.IX. & 09:00-14:00 & NNW 3 & $2 / 8$ & 404 & 200 & SSE \\
\hline $5.1 X$ & $11: 15-14: 45$ & SSW 3 > 1 & $2 / 8$ & $>200$ & - & local \\
\hline 7.-9.IX. & - & SSW-SSE & - & common & - & local \\
\hline 12.IX. & - & SE & - & common & - & local \\
\hline 13.IX., 15.-18.IX. & - & SSW-SSE & - & common & - & local \\
\hline 19.IX. & $10: 40-16: 40$ & W & $8 / 8$ & 7 & - & SSE \\
\hline 20.IX. & $09: 20-16: 45$ & NW 3 & $6>2 / 8$ & 220 & 129 & $\mathrm{~S}$ \\
\hline 21.IX. & $07: 15-13: 15$ & NW-N & $2 / 8$ & 45 & 31 & $\mathrm{~S}$ \\
\hline 22.IX. & $10.15-13.15$ & NW3 > W4 & $2 / 8$ & 71 & 50 & $\mathrm{SE}>\mathrm{E}$ \\
\hline 24.IX. & $07: 30-16: 45$ & NW7-8 & $8 / 3$ & 18 & 11 & SE \\
\hline 25.IX. & $08: 00-14: 00$ & NW 4-5 & $4 / 8$ & 2 & 1 & SSE \\
\hline 26.IX. & $10: 00-14: 15$ & E 3 & $4 / 8$ & 5 & 4 & SW \\
\hline 29.IX. & $10: 30-13: 30$ & NE 5 & $8 / 8$ & 0 & - & - \\
\hline 30.IX. & 09:00-13:30 & NW 10 & $1 / 8$ & 2 & 1 & local \\
\hline
\end{tabular}




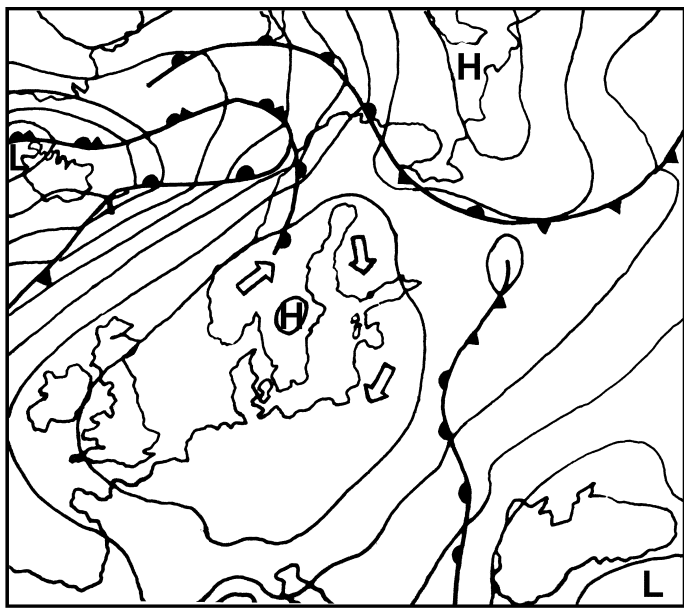

Fig. 2. Weather map over northern Europe on 20 September, 1998 at 00 UTC. The dot denotes the Porkkala Bird Tower. From: Amstblatt des Deutschen Wetterdienstes.

On this day at the Bird Tower, many individuals stopped their migratory flight and landed, and were not counted.

On 14 September 1998 in the parks and botanical garden in central Helsinki, a minimum of 56 stationary butterflies were counted (R. Hytönen). On a small field of fodder cabbage in the inland at Kalvola, there were $200 \mathrm{~V}$. atalanta on 13 September and 100 on 22 September (M. Nukarinen). Elsewhere in the country, the migration of $V$. atalanta was often observed as large aggregations on small forest meadows, often with flowering Cirsium. In one case, in Espoo, the butterflies arrived at the northern margin of a wide field and disappeared at its southern margin, many of them first circling to elevations of tens of metres (V. Solantie).

The insect migration of 20 September 1998 was clearly visible on the radar over Helsinki, but unfortunately due to a large number of aphids on the wing, it was not possible to distinguish the butterflies. As a result of clearing skies, the migration peaked around noon and remained elevated for the whole afternoon. Convection was strong up to an elevation of $3000 \mathrm{~m}^{*}$, and larger insects, possibly $V$. atalanta, were observed at that height. The upper limit of the main insect mass was at $1000 \mathrm{~m}$. The insects proceeded with the northern air current straight over the Gulf of Finland, a definite sign of true migration, not just of rising local insects (the birds typically stopped before the sea).

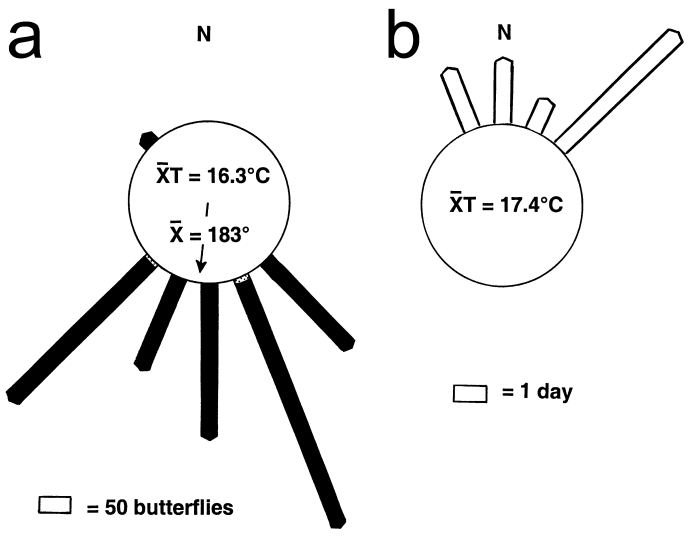

Fig. 3. The wind directions at Porkkala Bird Tower on 1-24 September, 1998. - a. Wind directions during the migrations of $V$. atalanta, as numbers of butterflies in each direction. Black arrow $=$ midwind $\pm<22.5^{\circ}$, stippled part $=$ midwind $\pm 22.5^{\circ}-45^{\circ}$. Average maximum temperatures and average direction of migrants inserted (20 NW fliers excluded). - b. Wind directions during empty days. Open arrows $=$ days without migrants. Average maximum temperatures inserted.

1999

$173 / 5060$. Poor year, with roughly $5 \%$ of the admirals of the previous year (Mikkola 2000). The Tower noted only 2 exx. S and 1 ex. SW.

\section{0}

$389 / 7178$. This autumn provided new data on Vanessa atalanta, although the yearly total from Finland was much lower than in 1998 (Mikkola 2001). The first inland migration was seen at PS: Siilinjärvi (around $63^{\circ} \mathrm{N}$ ) on 4 September, a total of 26 butterflies circling and gliding with a northern wind at heights of about 10-60 m (M. Ukkonen), and at Tampere (around $61^{\circ} 20^{\prime} \mathrm{N}$ ) on the same day, a strong migration with a northern wind; the next day only single individuals were seen (T. Itkonen).

From the Porkkala Bird Tower, the following numbers were counted on 20 August-20 September (unfortunately, no observation activity on 4 September, cf. above!): Vanessa atalanta 116 exx. (54 indet.), 102 of which received a direction: $2 \mathrm{E}, 1 \mathrm{~W}, 1 \mathrm{~N}$, all others SSE-SW; a few in W winds, otherwise the winds were from WNW-NNE; the temperature was between +10 and $+13^{\circ} \mathrm{C}$ on many good days. Other

* During the visible migration of $V$. atalanta on 20 September 1998, "bee-sized targets", presumably also V. atalanta, were numerous on the radar screen up to $2000 \mathrm{~m}$ (with a temperature of $+2-3{ }^{\circ} \mathrm{C}$, and single individuals temporarily visited the level of $3000 \mathrm{~m}\left(-2^{\circ} \mathrm{C}\right)$. 
migrants seen: Pieris brassicae 16 (4 indet.) exx. on 20 August-1 September, and one on 12 September. All except the last one were in at least $+15^{\circ} \mathrm{C}$ weather.

At the Porkkala Bird Observatory on the island of Rönnskär, an important observation series was made on 15-20 September, as the butterflies were recorded both from a $1400 \mathrm{~m}$ long transect around the island and from migration over the island $(\mathrm{K}$. Saarvola). Migration was seen on two days with $\mathrm{N}$ to NE winds, on 15 and 20 September, with 11 and 54 exx., respectively, at high elevation, many probably at $30 \mathrm{~m}$, to the south. No $V$. atalanta were seen on the transect. On 16-19 September, warm, weak winds from southern directions prevailed. The numbers of $V$. atalanta on these days on the transect were $21,18,8$ and 5 exx., but no migration was seen.

From the radar it was observed on 20 September 2000, that the bodies of the insect migrants over Porkkala, supposedly $V$. atalanta, the only large insects visually found to migrate in numbers on this day, were seen to be aligned more or less parallel to each other and along a south-north axis.

\section{1}

238/2423. In spite of a promising early season, the autumn was poor (Mikkola 2002). Only a few migrating $V$. atalanta were observed from the Tower: 17 September, 2 exx. W with the wind; 18 September, 4 exx. (1 indet.) with the wind; 19 September, 1 ex. W with the wind; 3 October, 2 exx. ESE, wind WSW; 12 October, 3 exx. S with the wind. A great influx of migrant Lepidoptera to Finland on 17-23 September 2001 from the southeast (30 species; Mikkola 2002) brought no additional wave of $V$. atalanta.

During these years, a certain synoptic weather situation often prevailed in days good for migration (Fig. 2): an Atlantic high pressure spread from the southwest to Fennoscandia and there was a low pressure area over northern Russia. The consequence was that fair but cool weather with northern winds prevailed in Finland.

\subsection{Interpretation of the data}

Results of the observation series from Finland from 1994-2001 can be summarized as follows:
1. Substantial numbers of Vanessa atalanta were observed to migrate in autumn into southern quarter directions. The flights seen took place at medium altitude, above the forests, often at around 20 to $100 \mathrm{~m}$ above the ground. According to radar observations, the main insect migration on 20 September 1998 extended to an altitude of around $1000 \mathrm{~m}$, and individual larger insects, probably Vanessa atalanta, flew well beyond that, up to $3000 \mathrm{~m}$.

2. The flight of $V$. atalanta was of the energysaving type, with slow wing flapping often interrupted by long periods of circling and gliding.

3. The $V$. atalanta migrations were aided by cool northern-quarter winds in sunny weather. The role of the wind in the orientation was seen in that after veering of the wind the flight continued for a while in a reversed direction.

4. During warmer southern-quarter winds the migrations were halted. On a line transect for counting of birds and butterflies, the butterflies were observed to be stationary in the terrain on these days.

5. The coastal line of the Gulf of Finland is nearly perpendicular to the direction of migrations. Migrations of the same type were seen at a few inland localities and at Hanko, around 90 $\mathrm{km}$ WSW, as well as probably on the radar screen over Helsinki. Therefore, it is supposed that the flow of migrants was even and not funneled by the Porkkala Peninsula.

6. The total number of butterflies counted in September in an imaginary observation tunnel estimated to be $500 \mathrm{~m}$ wide and $100 \mathrm{~m}$ high was 1240 exx. From this, an estimate for a 100-km line from Hanko to Helsinki can be made, assuming that the migratory flow was even (see above). Then a minimum of 250000 exx. traversed the line. If every second butterfly from the tunnel was noticed, half a million butterflies traversed the line during the month.

7. Migration of a different type, at a lower altitude using compass orientation or orientation against the wind, or both, could be observed at flower-rich meadows at a few inland localities. A change to the medium-elevation migratory flight could be seen in the circling of butterflies toward greater heights.

8. In flower-rich gardens or at sugar-feeding 
stations, aggregations of some 30-50 butterflies stayed for several days.

9. The numbers of autumn migrants fluctuated strongly between the years, loosely according to the strength of the arrival migration early in the season and to the size of the summer generation.

10. Three other seasonal migrants, Vanessa cardui, Pieris brassicae and Autographa gamma showed the same migratory behaviour as $V$. atalanta, but with much lower numbers of individuals counted. Of these, $P$. brassicae migrated on average earlier and, consequently, at higher temperatures than $V$. atalanta.

\section{Discussion}

Migration is a widespread phenomenon in insects and has evolved independently in almost all groups; a common thread of migratory behaviour is adaptation to shifting environments (e.g. Johnson 1969, Southwood 1977, Vepsäläinen 1978, Dingle 1979). Among the migrant insects of the temperate regions, the seasonally migrant Lepidoptera form the most remarkable group with regard to the numbers involved and the distances covered. Tens of species from several families spend the winter season exclusively in mild climatic conditions. In spring, the populations migrate north, often during successive generations. The most advanced migrants, among them Vanessa atalanta, reach the northern temperate to southern boreal zones more or less regularly.

The spring migrations are easily understandable as an evolutionary strategy. After the productive flowering season of the eremitic and steppe regions, the Mediterranean area included, these zones become uninhabitable because of the summer drought (cf. Stefanescu 2001). The newly hatched early-summer individuals migrate north. The populations are then able to invade a vast area at moderate to northern latitudes for reproduction.

Seasonal migrants reach northern latitudes mainly by using warm currents. However, that they would use the opposite currents to return to their overwintering grounds has been less clear. Such a movement would clarify the ecological and evolutionary significance of the migration to the north. The other alternatives for return migrations, low-altitude flights against the wind or into preferred compass directions, would supposedly create energetic difficulties. They may well be an essential part of the return movements, however.

The estimated total number of Vanessa atalanta traversing a $100 \mathrm{~km}$ stretch of Finnish southern coast in September 1998 - half a million butterflies - seems to be in line with the total number of actually observed specimens that year for Finland, ca.100 000. The real total of migrants may have been considerably higher, however, because according to the radar observations a great proportion may have migrated at high elevation, beyond the visible range. These considerations indicate that a substantial part of the population must have been on the move.

In many respects, the present observations agree with those for the Monarch (Danaus plexippus) in North America (e.g. Gibo 1986, Schmidt-Koenig 1993, Brower 1996). The flights of $V$. atalanta were supposedly above the boundary layer of the butterflies, i.e. the speed of the air current exceeded their flight speed (cf. Taylor 1974). In addition, the migrants probably were free of visual contact to the ground and therefore free of any needs of compensatory movements to the opposite direction (cf. Kennedy 1961, Mikkola 1986).

More than half a century ago, Larsen (1949) and Melnichenko (1935) observed in their classical studies on Autographa gamma and Loxostege sticticalis L., that the migratory swarms after an exodus rise advanced with the wind. From the tropical zone, the Desert Locust Schistocerca gregaria (Forskål) (e.g. Waloff 1958, Rainey 1963) and the African Armyworm Spodoptera exempta (Wlk.) (Brown et al. 1969) are the bestknown examples of insect species advancing in immense swarms with air currents.

In Europe, the extent to which the seasonal migrants perform return migrations has been unknown, except that there exist numerous local observations of flights near the ground against the wind or into a compass direction irrespective of the wind (see Williams 1958, Johnson 1969). In autumn, even the most advantageous southern air currents do not bring any Vanessa atalanta to the north (for September 2001, see above), negative evidence for selection of direction in this species.

In southern mountain passes, autumn migrants 
have apparently been funneled by the landscape formations (see Johnson 1969, Gatter 1981). However, Gatter (1981) describes the same synoptic weather situation as was given above for Porkkala (Fig. 2; see also figure 1.3a in Dennis [1993], and Tucker [1997]). The cold northern air currents inspired some high-elevation migrations, but "not frequently". That the migrants mostly flew against the wind (in the pass), may be an observational bias, caused by the difficulty in detecting mediumaltitude flights.

Showers (1997) presents interesting data on the southward migrations of Agrotis ipsilon (Hufnagel) (Noctuidae) with (meteorologically) low-altitude northern winds in North America. This may be a selective situation similar to Vanessa atalanta. In A. ipsilon, the development of the ovaries is slower in autumn than in spring, when the air currents provide faster transport.

In North America also a small insect seems to utilize northern winds on its autumn migrations. Taylor \& Reling (1986) observed that the catches with aircraft-mounted nets of the homopteran Empoasca fabae (Harris) were associated with winds from the N-NE.

I know of only one example where northern migrants seem to have arrived at a southern area with northern air currents. Sutton (1966) observed that in September in the southern Caspian area the numbers of many lepidopterous migrants increased following northern cold fronts. The daytime migrants, among them Vanessa atalanta, really proceeded flying in settled anticyclonic weather with the wind from the north or northwest.

The American Monarch Danaus plexippus is in a class of its own. In autumn, the adults migrate south to hibernate in very restricted areas, and in addition, part of the population flies back north in the spring, as elegantly shown by Brower (1996). Urquhart (1960), reporting on the southward migration, said that the north wind "brought in a huge cloud of Monarchs riding ahead of a cold front". The observations of Gibo (1986) and Schmidt-Koenig (1993) as well as the review of Brower (1996) give a thorough account of the southward migration of Monarchs in Eastern North America (see also Anonymous 1997). Perez et al. (1997), using clock-shifting techniques, confirmed that migrating Monarchs use sun com- pass orientation. According to Williams (1958), the Monarch is the only butterfly species that selects (cold) northerly winds for its return migrations.

The problem of sensing direction of movement high in the air has been discussed by Riley \& Reynolds (1986). Often insects in nightly highaltitude migration swarms keep their bodies parallel to each other or to the movement, i.e. downwind. Riley \& Reynolds (1986) and Drake \& Farrow (1988) suggest that the insects are provided with cues related to wind direction from the accelerative anisotropies of air movement associated with shear-induced (Kelvin-Helmholtz) waves in the atmosphere. The windward orientation was also observed in this study, both visually and through radar (although the species was not determined).

Thus, Vanessa atalanta is, along with Danaus plexippus, a species which shows regular autumnal return migrations, and is carried by northern winds selected by the butterflies themselves. This is a kind of antithesis to Gatehouse's (1994) prediction that the "variation of migratory potential and the stochastic effects of the wind" would "sample the landscape". Highly determined migrants decide when and where to go with the winds.

Recent results from Catalonia, Spain, by Stefanescu (2001) complete the view about the ecological strategy of Vanessa atalanta. This is roughly the direction headed by the Finnish $V$. atalanta, the distance being around $3000 \mathrm{~km}$. In 1998 , the peak migratory activity and the peak appearance of old individuals occurred in Catalonia roughly five weeks after the main migrations in Finland. This gives $85 \mathrm{~km}$ as the average daily flights. As a result of the migrations of the adults, the larvae may utilize highest quality nettles both in Spain, or elsewhere in the Mediterranean, in the winter season (Stefanescu 2001), and in Finland, or elsewhere in the North, in the early part of the summer season.

The "northerner flight" strategy of migration is probably true of several other seasonal migrants, although only low numbers were observed in this study. In general, these flights probably contain sufficient individuals and geographical coverage to abolish the "evolutionary dilemma" of the migrations to the north. The observed stationary 
nature of $V$. atalanta butterflies on warmer days with opposite wind direction indicates that the migration with the wind really is an evolved, innate behaviour. The most probable factor releasing it is the shortening day.

Acknowledgements. Sincere thanks are due to the patient ornithologists in the Porkkala Bird Tower and elsewhere, as well as to the many lepidopterologists who have made valuable observations. I thank Matti Leskinen, Division of Atmospheric Sciences, University of Helsinki, for radar notes and Irmeli Markkula, Pest Research Centre, Jokioinen, for notes on aphids. I am also grateful to Dr. C. Stefanescu (Barcelona) for constructive criticism of my manuscript.

\section{References}

Anonymous 1997: Monarchs and weather fronts in 1996. - Monarch Watch 5: 9.

Baker, R. R. 1968: A possible method of evolution of the migratory habit in butterflies. - Phil. Trans. R. Soc. (B) 253: 309-341.

Benvenuti, S., Dall'Antonia, P. \& Ioale, P. 1994: Migration pattern of the red admiral, Vanessa atalanta L. (Lepidoptera, Nymphalidae), in Italy. — Boll. Zool. 61: 343-351.

Brower, L.P. 1996: Monarch butterfly orientation: missing pieces of a magnificent puzzle. — J. Exp. Biol. 199:93-103.

Brown, E. S., Betts, E. \& Rainey, R. C. 1969: Seasonal changes in distribution of the African Armyworm, Spodoptera exempta (Wlk.) (Lep., Noctuidae), with special reference to Eastern Africa. — Bull. Entomol. Res. 58: 661-728.

Dennis, R. L. H. 1993: Butterflies and climate change. Manchester University Press. Manchester. 302 pp.

Dingle, H. 1979: Ecology and evolution of migration. In: Gauthreaux, S. A. (ed.), Animal migration, orientation, and navigation: 1-101. - Academic Press.

Drake, V. A. \& Farrow, R. A. 1988: The influence of atmospheric structure and motions on insect migration. - Ann. Rev. Entomol. 33: 183-210.

Felt, E. P. 1925: Dispersal of butterflies and other insects. - Nature 116: 365-368.

Felt, E. P. 1928: Dispersal of insects by air currents. - N. Y. St. Mus. Bull. 274: 59-129.

Gatehouse, A. G. 1994: Insect migration: variability and success in a capricious environment. - Res. Popul. Ecol. 36: 165-171.

Gatter, W. 1981: Insektenwanderungen. - Kilda-Verlag. Münster. 94 pp.

Gibo, D. L. 1986: Flight strategies of migrating monarch butterflies (Danaus plexippus L.) in southern Ontario. - In: Danthanarayana, W. (ed.), Insect flight: Dispersal and migration: 172-184. Springer-Verlag. Berlin Heidelberg. 289 pp.
Johnson, C. G. 1969: Migration and dispersal of insect by flight. - Methuen \& Co. Ltd. London. 763 pp.

Kaisila, J. 1962: Immigration und Expansion der Lepidopteren in Finnland in den Jahren 1869-1960. — Acta Entomol. Fennica 18: 1-452.

Kennedy, J. S. 1961: A turning point in the study of insect migration. - Nature 189: 785-791.

Kettlewell, H. B. D. 1952: A possible genetic explanation and understanding of continuous brooded insects. Nature 169: 832-833.

Larsen, E. B. 1949: Activity and migration of Plusia gamma L. Studies in the activity of insects. III. - Biol. Meddr. 21: 1-32.

Melnichenko, A. N. 1935: [Regularities of mass flying of the adult Loxostege sticticalis L. and the problem of prognosis of their flight migrations.] - Bull. Plant Prot., Leningrad Ser. 1. Ent., 17. Rev. appl. Ent. (A) 26, 429. 54 pp. [In Russian].

Mikkola, K. 1967: Immigrations of Lepidoptera, recorded in Finland in the years 1946-1966, in relation to aircurrents. — Ann. Zool. Fenn. 2: 124-139.

Mikkola, K. 1981: [The weather and migrations of insects in Finland.] - Baptria 6: 81-84. [In Finnish with Swedish abstract].

Mikkola, K. 1986: Direction of insect migrations in relation to wind. - In: Danthanarayana, W. (ed.), Insect flight: Dispersal and migration: 152-171. SpringerVerlag. Berlin Heidelberg. 289 pp.

Mikkola, K. 1996a: [The weather and migrations of insects in Finland in 1994.] — Baptria 21: 13-16. [In Finnish with English abstract].

Mikkola, K. 1996b: [The weather and migrations of insects in Finland in 1995.] — Baptria 21: 133-140. [In Finnish with English abstract].

Mikkola, K. 1997: [The weather and migrations of insects in Finland in 1996.] — Baptria 22: 77-83. [In Finnish with English abstract].

Mikkola, K. 1998: [The weather and migrations of insects in Finland in 1997.] — Baptria 23: 140-144. [In Finnish with English abstract].

Mikkola, K. 1999: [The weather and migrations of insects in Finland in 1998.] — Baptria 24: 95-102. [In Finnish with English abstract].

Mikkola, K. 2000: [The weather and migrations of insects in Finland in 1999.] — Baptria 25: 33-43. [In Finnish with English abstract].

Mikkola, K. 2001: [The weather and migrations of insects in Finland in 2000.] — Baptria 26: 93-98. [In Finnish with English abstract].

Mikkola, K. 2002: [The weather and migrations of insects in Finland in 2001.] — Baptria 27: 55-59 [In Finnish with English abstract].

Perez, S. M., Taylor, O. R. \& Jander, R. 1997: A sun compass in monarch butterflies. - Nature 387: 29.

Pollard, E. 1982: Observations on the migratory behaviour of the painted lady butterfly, Vanessa cardui (L.) (Lepidoptera, Nymphalidae). — Entomol. Gazette 33: 99103. 
Rainey, R. C. 1963: Meteorology and the migrations of Desert Locusts. — Tech. Notes Wld. Met. Org. No. 54, $115 \mathrm{pp}$.

Riley, J. R. \& Reynolds, D. R. 1986: Orientation at night by high-flying insects. - In: Danthanarayana, W. (ed.), Insect flight: Dispersal and migration: 71-87. SpringerVerlag. Berlin Heidelberg. 289 pp.

Schmidt- Koenig, K. 1993: Orientation and autumn migration in the monarch butterfly. - In: Malcolm, S. B. \& Zalucki, M. P. (eds.), Biology and conservation of the monarch butterfly: 275-283. Publications of the Los Angeles County Museum, Los Angeles.

Showers, W. B. 1997: Migratory ecology of the Black cutworm. - Ann. Rev. Entomol. 42: 393-425.

Southwood, T. R. E. 1977: Habitat, the templet for ecological strategies? - J. Anim. Ecol. 46: 337-365.

Stefanescu, C. 2001: The nature of migration in the red admiral butterfly Vanessa atalanta: evidence from the population ecology in its southern range. - Ecol. Entomol. 26: 525-536.

Sutton, S. L. 1966: South Caspian insect fauna, 1961. II. Migration, status and distribution of certain insect spe- cies in Northern Persia. — Trans. R. Ent. Soc. London 118: 51-72.

Taylor, L. R. 1974: Insect migration, flight periodicity and the boundary layer. - J. Anim. Ecol. 43: 225-238.

Taylor, R. A. J. \& Reling, D. 1986: Preferred wind direction of long-distance leafhopper (Empoasca fabae) migrants and its relevance to the return migration of small insects. - J. Anim. Ecol. 55: 1103-1114.

Tucker, M. 1997: The red admiral butterfly. — Butterfly Conservation, Colchester. 32 pp.

Urquhart, F. A. 1960: The Monarch Butterfly. - University of Toronto Press. Toronto. $361 \mathrm{pp}$.

Vepsäläinen, K. 1978: Wing dimorphism and habitats of Gerris Fabr.: Determination and adaptive significance. — In: Dingle, H. (ed.), Evolution of insect migration and diapause: 218-253. Springer-Verlag, New York.

Waloff,Z. 1958: The behaviour of locusts in migrating swarms. — Proc. X Int. Congr. Ent. (Montreal, 1956) 2: 567-570.

Williams, C. B. 1930: The migration of butterflies. - Biological Monographs and Manuals IX: 1-473.

Williams, C. B. 1958: Insect migration. - Collins, London. 235 pp. 